\title{
Copper toxicity to microscopic stages of giant kelp Macrocystis pyrifera: interpopulation comparisons and temporal variability
}

\author{
B. S. Anderson ${ }^{1,2}$, J. W. Hunt ${ }^{1,2}$, S. L. Turpen ${ }^{1,2}$, A. R. Coulon ${ }^{1,2}$, M. Martin ${ }^{2}$ \\ ${ }^{1}$ Institute of Marine Sciences, University of California, Santa Cruz, California 95064, USA \\ ${ }^{2}$ Marine Pollution Studies Laboratory, California Department of Fish and Game, Coast Route 1, Granite Canyon, Monterey, \\ California 93940, USA*
}

\begin{abstract}
Experiments were conducted to evaluate temporal and geographic variation in sensitivity of microscopic stages of giant kelp Macrocystis pyrifera to copper. Spores from kelp sporophylls collected from different locations and at different times of the year were exposed to series of copper concentrations following a standard toxicity test procedure. After $48 \mathrm{~h}$ static exposures, toxicity was determined by measuring 2 test endpoints: germination success and growth of germination tubes. The sensitivity of these endpoints to copper was also compared with the sensitivity of longer-term reproductive endpoints: sporophyte production and sporophyte growth. No significant differences in response to copper were found among spores from different collection sites. Variability between 4 tests conducted quarterly throughout the year was greater than that between 3 tests done consecutively within 1 mo, indicating temporal variability in response to copper. Long-term reproductive endpoints were more sensitive to copper than were short-term vegetative endpoints, with No Observed Effect Concentrations of $<10 \mu \mathrm{g} \mathrm{l}^{-1}$ for sporophyte production, $10 \mu \mathrm{g} \mathrm{1^{-1 }}$ for sporophyte growth, $10 \mu \mathrm{g} \mathrm{l}^{-1}$ for germ-tube growth, and $50 \mu \mathrm{g} \mathrm{l}^{-1}$ for germination inhibition.
\end{abstract}

\section{INTRODUCTION}

The majority of California's municipal and industrial waste water is discharged into the nearshore coastal environment. California waste dischargers are currently required to perform chemical and biological monitoring of waste effluents. Chemical measurements monitor concentrations of specific chemical constituents, while laboratory biological tests measure whole effluent toxicity to aquatic organisms.

Biological toxicity tests currently in use evaluate effluent toxicity generally by measuring short-term toxic effects such as mortality using adult stages of fresh water fish species. These tests have been considered inadequate to protect marine populations because they use less sensitive life stages of nonindigenous species. In contrast, new toxicity tests attempt to estimate chronic toxicity by measuring sublethal effects such as abnormal development, repro-

\footnotetext{
- Address for correspondence (to first author)
}

ductive failure, or growth of sensitive life stages (Bay et al. 1983, Lussier et al. 1985, ASTM 1987, Dinnel et al. 1987. Anderson \& Hunt 1988, Middaugh et al. 1988, Hunt \& Anderson 1989, Martin et al. 1989). By using more sensitive early life stages of indigenous species, the new tests may better indicate the potential impacts of discharged waste on marine populations, although there are clear limitations in extrapolating laboratory results to the field. Because species have variable sensitivities to toxicants, new bioassay protocols have been developed with species representing a variety of phyla.

Included in this 'multispecies' approach is the giant kelp Macrocystis pyrifera, an important primary producer in near-shore marine communities. $M$. pyrifera is an appropriate toxicity test species because kelp is amenable to laboratory culture and relatively sensitive to toxicants, and kelp forests provide a significant ecological and economic resource to California (Foster \& Schiel 1985). There is concern over the effects of pollution on $M$. pyrifera and its associated marine communities because of the proximity of kelp forests to nearshore pollution. $M$. pyrifera has been cultured 
extensively in laboratory studies and its life history has been well described (North 1971, North et al. 1982, Lüning 1980). Its use in toxicity studies has been limited (Smith \& Harrison 1978, James et al. 1987. Anderson \& Hunt 1988)

Two giant kelp toxicity tests were developed as part of an effort by the California State Water Resources Control Board to implement new bioassay tests for monitoring effluent toxicity: a short-term $48 \mathrm{~h}$ test and a longer-term 16 to $20 \mathrm{~d}$ test (Anderson \& Hunt 1988). The $48 \mathrm{~h}$ test has 2 endpoints: germination of the haploid zoospores, and initial growth of the 'germ-tube' of the developing gametophyte. The longer-term test focuses on sporophyte 'production' and is used for comparison with the short-term test. Sporophytes are the product of sexual reproduction between male and female gametophytes.

Several aspects of the Macrocystis pyrifera toxicity test required further study before the test was implemented in the state's regulatory program. Because testing laboratories collect kelp reproductive blades (sporophylls) from local kelp populations throughout the year, it was necessary to evaluate interpopulation and temporal effects on test performance. Three experiments were conducted as a part of this evaluation. The first compared results of concurrent tests using sporophylls collected from different locations along the California coast. The second compared the variation among tests conducted quarterly throughout the year with variation among consecutive tests conducted during the same month. The third compared the sensitivity of short-term vegetative endpoints with long-term reproductive endpoints. A reference toxicant, copper chloride, was used for all experiments. Copper is found in high concentrations in municipal sewage (Harrison 1982, SCCWRP 1986) and power plant effluents (Martin et al. 1977, Harrison 1982), and copper has been used in previous toxicity tests with other algal species, allowing for direct comparisons of sensitivity.

\section{METHODS}

Facilities. All toxicity experiments were conducted between November 1987 and December 1988 at the California Department of Fish and Game's Marine Pollution Studies Laboratory (MPSL), located on the Big Sur coast in Monterey County, California, USA. Laboratory seawater has been shown to have very low background trace metal concentrations (Martin et al. 1981), and copper concentrations in control seawater in this study were below detection limits $\left(<0.6 \mu \mathrm{g} \mathrm{l}^{-1}\right)$.

Toxicity tests. Motile zoospores were placed in toxicant solutions and exposed continuously for $48 \mathrm{~h}$ in the short-term test and 16 to $20 \mathrm{~d}$ in the long-term test. The toxicity test methods have been previously described (Anderson \& Hunt 1988). The short-term test has 2 endpoints: percent germination, measured by counting 100 spores and scoring them as either germinated or not germinated, and germ-tube growth, measured as length from the edge of the spore case to the tip of the germ-tube. Growth was measured with an ocular micrometer on 10 randomly selected spores from each test container. Sporophyte production was used to indicate toxicity in the long-term tests. Zoospores were obtained from mature reproductive blades (sporophylls) collected by skindivers the day before each test from kelp beds at either Granite Canyon or Monastery Beach, Monterey County. They were stored at $12^{\circ} \mathrm{C}$ before testing.

Sensitivity of different kelp populations. To compare the sensitivity of kelp zoospores from geographically isolated Macrocystis pyrifera populations, sporophylls were collected from 4 different California kelp beds: La Jolla Cove, San Diego County $\left(32^{\circ} 45^{\prime} \mathrm{N}\right.$, $\left.117^{\circ} 15^{\prime} \mathrm{W}\right) ;$ Abalone Cove, Los Angeles County $\left(33^{\circ} 50^{\prime} \mathrm{N}, 118^{\circ} 30^{\prime} \mathrm{W}\right)$; Campus Point, Santa Barbara County $\left(34^{\circ} 30^{\prime} \mathrm{N}, 119^{\circ} 50^{\prime} \mathrm{W}\right)$; and Monastery Beach, Monterey County $\left(36^{\circ} 32^{\prime} \mathrm{N}, 125^{\circ} 56^{\prime} \mathrm{W}\right)$. Three groups of sporophylls were collected on December 8, 1988; 2 groups ( $\mathrm{La}$ Jolla and Abalone Cove) were blotted and placed in coolers at $9{ }^{\circ} \mathrm{C}$ and transported overnight to MPSL. The third group (Monastery Beach) was stored overnight in a refrigerator at $5{ }^{\circ} \mathrm{C}$ at MPSL. The sporophylls from Campus Point were collected on December 1, placed in flowing seawater (at ambient temperature, ca $15^{\circ} \mathrm{C}$ ) in a greenhouse, then blotted and placed in a cooler on December 8, and transported overnight to MPSL.

On December 9, sporophylls from each site were rinsed in $0.2 \mu \mathrm{m}$ filtered seawater, then placed in separate beakers filled with $1 \mathrm{l}$ of $0.2 \mu \mathrm{m}$ filtered seawater $\left(13^{\circ} \mathrm{C}\right)$ for $1 \mathrm{~h}$ to allow zoospore release. Zoospores were then pipetted into toxicant solutions in test containers that held 2 microscope slides. The first microscope slide was removed to quantify germination and germ-tube growth after $48 \mathrm{~h}$. At this time the lights were changed from cool-white fluorescent to full-spectrum Vitalights ${ }^{\circledR}\left(50 \mu \mathrm{E} \mathrm{m} \mathrm{m}^{-2} \mathrm{~s}^{-1}\right.$, to facilitate gametogenesis), and nutrients were added [PES (Provasoli 1968), minus EDTA-chelated iron, plus germanium dioxide to control diatoms (Markham \& Hagmeier 1982)]. Test solutions were changed on Days 4, 8 and 12 . The second slide was removed after $16 \mathrm{~d}$. Sporophyte numbers were counted in three $0.2 \times 18.0$ $\mathrm{mm}$ transects on each replicate slide at $100 \times$ magnification with a compound microscope. Total numbers of sporophytes were counted rather than the percentage of female gametophytes with sporophytes because the number of female gametophytes was too dense to allow 
accurate counting (see 'Endpoint comparisons' for explanation). Four concentrations and a control $(0,18$, 32,56 , and $100 \mu \mathrm{g}^{-1}$ copper), each replicated 5 times, were compared for each test using Analysis of Variance (ANOVA) followed by Dunnett's multiple comparison test. The percent germination data were first transformed to the arcsine of their square root. Sporophyte counts and length measurements were considered to be nested in each replicate for the ANOVA (Underwood 1981). For each test, the No Observed Effect Concentration (NOEC) was calculated as the highest concentration not significantly different from the control at $\mathrm{p}=0.05$. The 4 tests were compared to each other using a 2-way ANOVA (copper concentration and population). This was followed by a Student-Newman-Keuls multiple comparison test (SNK) to determine significant differences between tests (Zar 1974).

Temporal variability. Four short-term (48 h) copper experiments were conducted quarterly in February, May, August, and October 1989 to evaluate temporal variability. The copper concentrations tested were as follows: Test $1=0,56,100,180,320,560 \mu \mathrm{g} 1^{-1}$; Test 2 $=0,32,56,100,180,320 \mu \mathrm{g} 1^{-1}$; Tests 3 and $4=0,10$, $18,32,56,100,180 \mu \mathrm{g} 1^{-1}$.

All data were analyzed using analysis of variance (ANOVA) followed by Dunnett's multiple comparison test as above. A 2-way ANOVA (copper concentration and test date) was used to compare the percent germination data from the 4 tests.

A 3-way nested ANOVA (copper concentration, test date, and replicate container) was used to compare copper effects on germ-tube length. For the analyses, the germ-tube length measurements were considered to be nested within the replicate container and test date. Only results at matching copper concentrations $\left(0,56,100\right.$, and $\left.180 \mu \mathrm{g} \mathrm{I}^{-1}\right)$ were used to compare between-test differences.

Three short-term tests were conducted in October, and the results of these 3 tests were compared to the quarterly tests. These tests ('consecutive tests') were designed to assess a number of factors affecting variability, and the methods differed somewhat from those used in the quarterly tests. The differences involved the source of the sporophylls and the number of spores distributed to each test container. For all 3 consecutive tests, an adult plant was marked in the kelp bed at Granite Canyon and used as the sporophyll source Equal weights (116 g) of sporophylls were placed in 21 of $0.2 \mu \mathrm{m}$ filtered seawater at the start of each test. After 1.5 $\mathrm{h}$ the spore density was calculated and adjusted so that ca $3 \times 10^{6}$ spores were pipeted in $0.5 \mathrm{ml}$ water into each test container. After $48 \mathrm{~h}$ the test slides were removed and the endpoints quantified. Copper concentrations were $0,10,32,56,100$, and $180 \mu \mathrm{g} 1^{-1}$. An $18 \mu \mathrm{g} 1^{-1}$ test concentration was added to the final test. Only results at copper concentrations matching the quarterly tests $(0$, 56,100 , and $180 \mu \mathrm{g} \mathrm{l}^{-1}$ ) were used to compare betweentest differences and differences between the 3 consecutive tests and the 4 quarterly tests. The statistical methods were the same as t' se used in the 4 quarterly tests, except that 3 tests were compared instead of 4 .

Endpoint comparisons. One experiment was conducted to compare the relative sensitivity of several endpoints to copper. The initial procedures were the same as those used in the $48 \mathrm{~h}$ experiments, except that 3 microscope slides were placed in each test container at the start of the experiment. Lighting was provided by Vitalights $^{\circledR}\left(50 \mu \mathrm{E} \mathrm{m}^{-2} \mathrm{~s}^{-1}\right)$, nutrients (as above) were added during water changes on Days 4, 8, and 12. After $48 \mathrm{~h}$ one slide was removed and germination and germtube growth were quantified following the standard $48 \mathrm{~h}$ protocol. After $19 \mathrm{~d}$ a second slide was removed and the effect of copper on sporophyte production was evaluated. Sporophyte production was quantified in this experiment as the percentage of female gametophytes producing sporophytes. This was done to minimize bias that might arise from an unequal number of female gametophytes on replicate slides. On Day 20, the final slide was removed and the effect of copper on sporophyte growth was quantified. Sporophyte length was measured in microns with an ocular micrometer at $100 \times$ magnification. The first 10 sporophytes encountered in a $0.2 \times 18.0 \mathrm{~mm}$ transect across the slide were measured in each replicate. One-way ANOVA followed by Dunnett's multiple comparison test was used to determine NOEC's for each endpoint.

Reference toxicant verification and water chemistry. Copper concentrations were measured using samples taken at the beginning and end of each test and at each water change. One replicate from each concentration was sampled and analyzed using a Perkin Elmer Model 603 atomic absorption spectrophotometer (see Bruland et al. 1979 for analytical procedure). Unless otherwise noted, all reported copper values are analytically verified total copper concentrations. Identical test solutions from the same mixing flasks were used in the interpopulation experiment, and these were not measured.

Dissolved oxygen, $\mathrm{pH}$, salinity, and temperature were measured at the beginning and end of each experiment.

\section{RESULTS}

\section{Sensitivity of different kelp populations}

The results of the interpopulation experiment indicate that there is little difference in response to copper between isolated populations of Macrocystis pyrifera. There was a significant difference in germination between populations (ANOVA, $p=0.05$ ), but this 

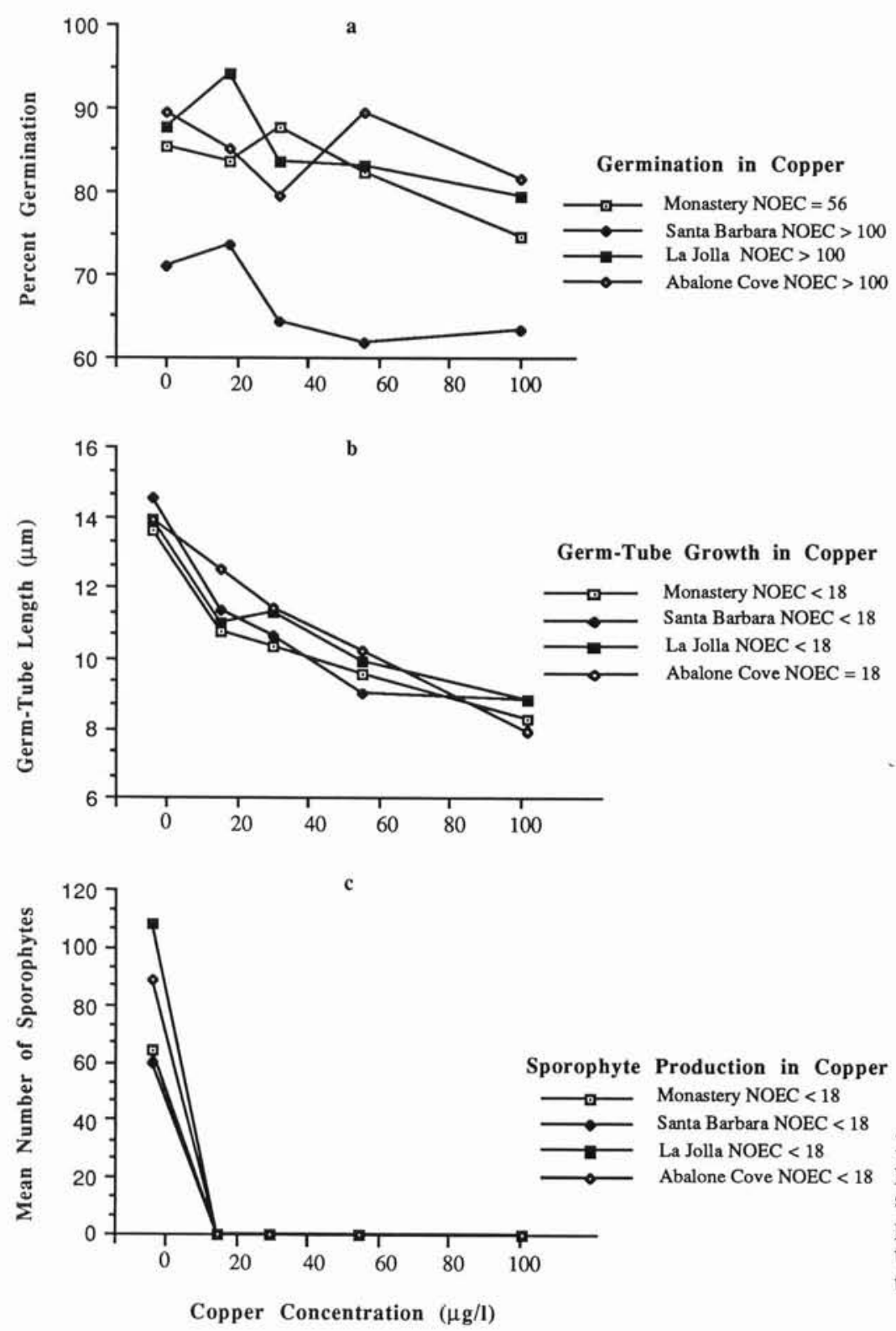

Fig. 1. Macrocystis pyrifera. Results of interpopulation experiment comparing relative sensitivities of 4 California kelp populations to copper. (a) Germination rates in copper; (b) germtube growth in copper; (c) sporophyte production in copper. NOEC: No Observed Effect Concentration

difference was a result of low germination rates in the Santa Barbara sporophylls (SNK, $\mathrm{p}=0.05$; Fig. 1a to c). These sporophylls were collected $8 \mathrm{~d}$ before the experiment and this apparently affected germination rates. If the germination data is transformed so that all of the germination rates are given as a percentage of the controls (i.e. the controls for each population are considered to be $100 \%$ germinated), then there is no significant difference between the populations (ANOVA, $\mathrm{p}=$ 0.11). All of the spores showed slight germination inhibition in response to copper, but the only statistically significant decrease occurred with the Monastery Beach spores exposed to $100 \mu \mathrm{g} \mathrm{l}^{-1}$ (NOEC $=56 \mu \mathrm{g} \mathrm{l}^{-1}$; Fig. 1a).

The germ-tube growth data showed no significant difference between the different spore sources (ANOVA, $p_{\mathrm{s}}>0.05$ ). The NOEC for germ-tube growth was less than the lowest test concentration $\left(18 \mu \mathrm{g} \mathrm{l^{-1 }}\right)$ at Monastery, Santa Barbara, and La Jolla, while Abalone Cove had a NOEC of $18 \mu \mathrm{g} \mathrm{l}^{-1}$. The response curves were similar for the 4 sporophyll sources (Fig. 1b).

Sporophyte production was inhibited at the lowest copper concentration $\left(18 \mu \mathrm{g} \mathrm{l}^{-1}\right)$ for all of the spore sources tested (Fig. 1c).

\section{Temporal variability}

Kelp zoospore germination was inhibited at different copper concentrations in the 4 quarterly tests, with 
a Germination

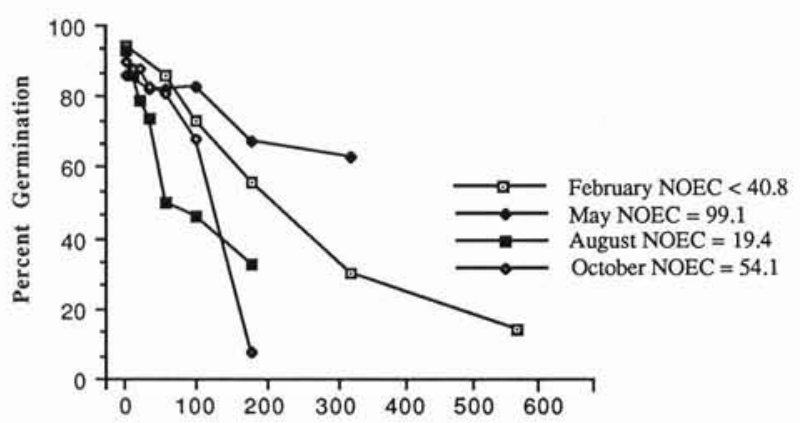

b Germ-Tube Growth

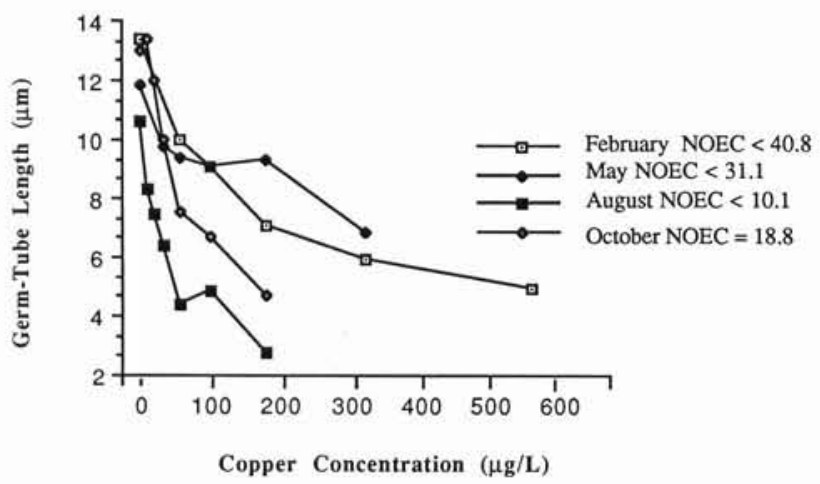

Fig. 2. Macrocystis pyrifera. Results of 4 quarterly copper experiments conducted in 1989. (a) Germination rates in copper; (b) germ-tube growth in copper. NOEC: No Observed Effect Concentration

NOEC's ranging from 99.1 to $19.4 \mu \mathrm{g} \mathrm{l}^{-1}$ (Fig. 2a, b). The germination response to copper was significantly different among tests done at different times of the year $(\mathrm{p}<0.0005)$, and there was a significant interaction between copper concentration and test date $(\mathrm{p}<$ 0.0005). While the results of the February and May experiments were not significantly different from each other, all other test comparisons showed significant differences (SNK, $\mathrm{p}=0.05$ ).

There were significant differences in the inhibition of germ-tube growth among the 4 experiments (p < 0.0005 ), with NOEC's ranging from $<40.8$ to $<10.1 \mu \mathrm{g}$ $\mathrm{I}^{-1}$. There was a significant interaction between test date and copper concentration $(p<0.01)$. Germ-tube growth inhibition was not significantly different in the February and May tests but all other test combinations were significantly different from each other (SNK, p = 0.05).

Results of the 3 consecutive copper experiments conducted in October were less variable than the 4 quarterly tests (Fig. 3a, b). The NOEC's for inhibition of germination were $55.8,94.5$, and $54.1 \mu \mathrm{g} \mathrm{l^{-1 }}$ for Tests 1 through 3 , respectively. Though there were differences a Germination

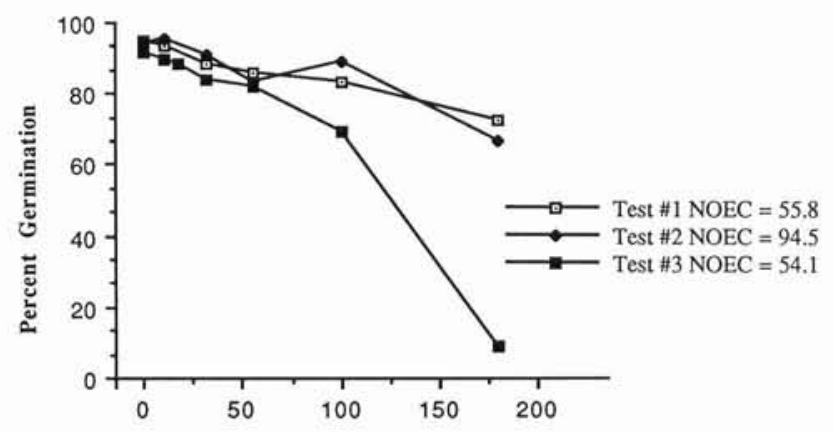

b Germ-Tube Growth

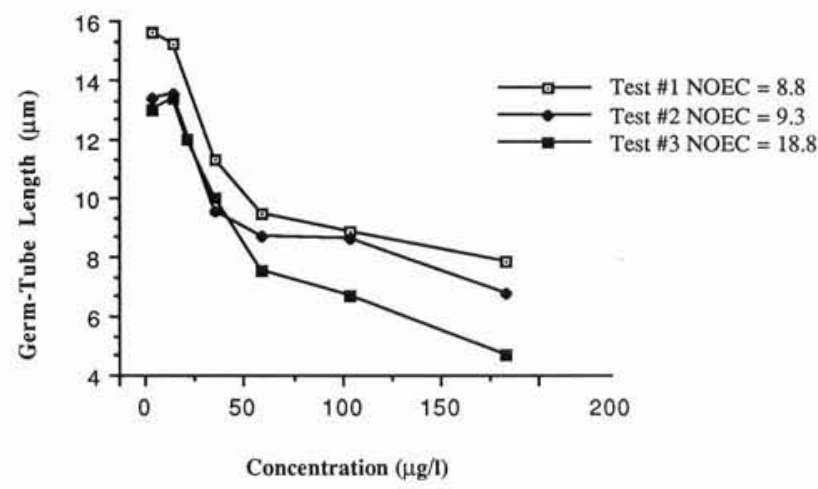

Fig. 3. Macrocystis pyrifera. Results of 3 consecutive copper experiments conducted in October 1989. (a) Germination rates in copper; (b) germ-tube growth in copper. NOEC: No Observed Effect Concentration

in response at the highest copper concentrations, differences in germination were not significant between the 3 tests $(p=0.1321)$. There was no statistical interaction between test number and copper concentration ( $\mathrm{p}=0.4918$; for the ANOVA's, 'test number' in the 3 consecutive tests equated with 'test date' in the 4 quarterly tests).

The NOEC's for inhibition of germ-tube growth were $8.8,9.3$, and $18.8 \mu \mathrm{g} 1^{-1}$ for the 3 tests. The difference in NOEC's in the growth data may be partially due to the range of copper concentrations used in the 3 experiments. The first 2 tests used a $10 \mu \mathrm{g} \mathrm{l} \mathrm{l}^{-1}$ but not an $18 \mu \mathrm{g} \mathrm{l}^{-1}$ (nominal) concentration. There was a significant difference in the effect of copper on germ-tube growth among the 3 consecutive tests $(\mathrm{p}<$ $0.0005)$. This difference was less significant, however, than among the 4 quarterly tests, based on critical values from the respective ANOVA's. The F ratio for germ-tube growth data from the 3 consecutive tests was 13.44, while the $\mathrm{F}$ value for growth data from the 4 quarterly tests was 26.27 . The interaction of test date and copper concentration was significant for the 4 quarterly tests, but there was no significant interaction 

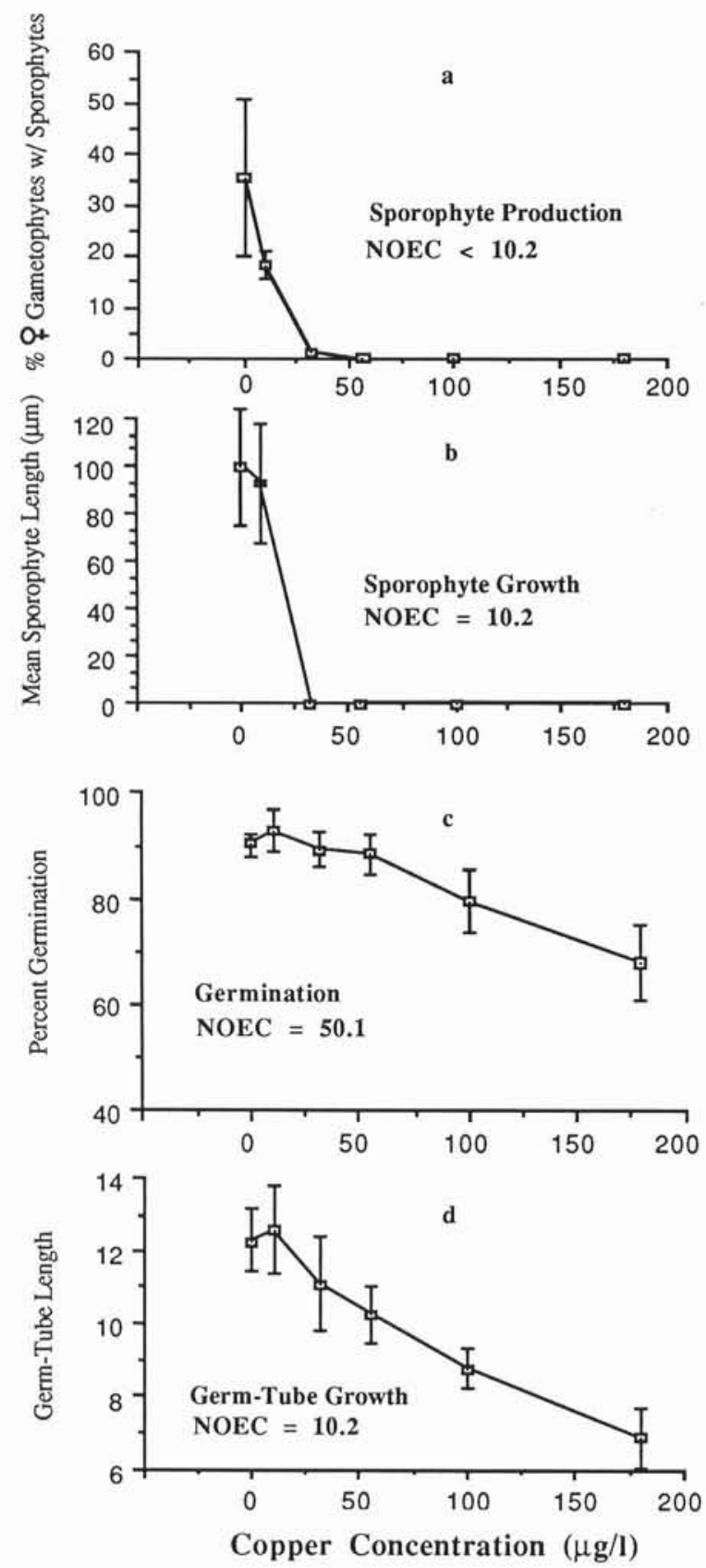

Fig. 4. Macrocystis pyrifera. Results of experiment comparing the relative sensitivity of long-term (19 to $20 \mathrm{~d})$ endpoints $(\mathrm{a}, \mathrm{b})$ vs short-term $(48 \mathrm{~h})$ endpoints $(\mathrm{c}, \mathrm{d})$. Mean $\pm 1 \mathrm{SD}(\mathrm{N}=5)$. NOEC: No Observed Effect Concentration

between concentration and test number for the 3 consecutive tests $(p>0.05)$.

\section{Endpoint comparison}

Results of the $20 \mathrm{~d}$ long-term experiment comparing 4 different endpoints showed that sporophyte produc- tion was more sensitive to copper than sporophyte growth, spore germination or germ-tube growth (Fig. $4 \mathrm{a}$ to d). The percentage of female gametophytes producing sporophytes declined at the lowest test concentration, $10.2 \mu \mathrm{g} \mathrm{l}^{-1}$ (NOEC $<10.2 \mu \mathrm{g} \mathrm{l^{-1 }}$; Fig. 4a). Once produced, the sporophytes appeared to grow in the lowest copper concentration $\left(\mathrm{NOEC}=10.2 \mu \mathrm{g} \mathrm{l}^{-1}\right.$; Fig. $4 \mathrm{~b})$, although the sizes of the sporophytes present were variable. There were so few sporophytes present in the $32 \mu \mathrm{g} \mathrm{I}^{-1}$ concentration that it was impossible to measure an adequate number for a statistical comparison. Germination was inhibited at $90.6 \mu \mathrm{g} \mathrm{l^{-1 }}$ copper (NOEC $=50.1 \mathrm{Mg} \mathrm{1}^{-1}$; Fig. 4c) and germ-tube growth was inhibited at $31.1 \mu \mathrm{g} \mathrm{I}^{-1}\left(\mathrm{NOEC}=10.2 \mu \mathrm{g} \mathrm{l}^{-1}\right.$; Fig. $\left.4 \mathrm{~d}\right)$.

\section{Physical and chemical measurements}

Dissolved oxygen concentration for all experiments ranged from 6.0 to $8.0 \mathrm{mg} \mathrm{l}^{-1}$. Test solution $\mathrm{pH}$ ranged from 7.8 to 8.3 . Salinity ranged from 35 to $37 \%$ in all experiments except one: salinity values in the first quarterly copper test were abnormally high, ranging from $35 \%$ at the start of the test to $47 \%$ at the end. The increased salinity in this test resulted from evaporation from the open containers over the last $24 \mathrm{~h}$ of the test; subsequent tests used covered containers. We have found Macrocystis pyrifera gametophytes to be surprisingly tolerant to elevated salinities. The results of this experiment did not appear to be affected by the increase because the spores had germinated and grown before the salinities increased. Temperature in the experiments ranged from 13 to $15^{\circ} \mathrm{C}$.

\section{DISCUSSION}

\section{Relative sensitivity of different kelp populations}

Our results indicate no significant difference in copper sensitivity among the 4 kelp populations compared. There was no significant difference among populations in the effect of copper on germ-tube growth, and there was no significant difference in germination among 3 of the 4 populations. The overall germination percentage was significantly lower for the sporophylls collected from Santa Barbara (due to the longer storage time mentioned earlier), but this did not appear to be related to copper toxicity because germination rates in the controls were low, also. Despite the low overall germination of the Santa Barbara spores, there was no significant difference among the 4 populations for germination results expressed as percentages of the controls. No Observed Effect Concentrations (NOEC's) for germination were similar among the 4 spore sources (Fig. 1a). 
Although the relative numbers of sporophytes produced varied between the different spore sources, the inhibition of sporophyte production by copper was the same. Sporophyte production was completely inhibited in all of the cultures at the lowest test concentration, 18 $\mu \mathrm{g}^{-1}$ (Fig. 1c). Because we evaluated the effect of copper on 3 different endpoints, each having varying degrees of sensitivity, a wide range of copper concentrations were tested. Including more concentrations between 0 and $18 \mu \mathrm{g} \mathrm{l}^{-1}$ would have given more information on inhibition of sporophyte production.

While the results of this experiment indicate little difference in copper sensitivity between different populations of Macrocystis pyrifera, it should be noted that it was conducted at only one time and with sporophylls collected from only 4 locations. It is possible that a more extensive experiment with more locations tested over the course of a year might reveal greater differences in kelp sensitivity. Geographical differences in physiology have been demonstrated for temperature tolerance by gametophytes (L. Deysher unpubl.) and sporophytes (North 1971), and for photosynthesis in sporophytes (Zimmerman 1988). Ecotypic differences in physiology have been reported for Laminaria saccharina (Gerard 1988), and geneticallybased variability in tolerance to copper have been reported for other macroalgal species (Russell \& Morris 1970, Hall et al. 1981, Reed \& Moffat 1983).

\section{Temporal variability}

These experiments indicate that there is temporal variability in the sensitivity of Macrocystis pyrifera to copper. There was greater variability between experiments conducted over the course of a year than between experiments conducted within the same month. There were differences in NOEC's in the 4 quarterly tests and a significant difference in spore germination. Germination and germ-tube growth were less sensitive in February and May than in August and October. All test comparisons other than February and May were significantly different (SNK, $p>0.05$ ). There was a significant test date-copper interaction in these experiments. Between-test variability was lower in the 3 consecutive October experiments; there was no significant difference in germination between these 3 tests.

Germ-tube growth was inhibited at different copper concentrations in the 4 quarterly tests (SNK, $\mathrm{p}=0.05$ ). The interaction of test date and copper effect was more significant in the 4 quarterly tests than in the 3 consecutive tests. There was a significant difference between the 3 consecutive tests but the effect of test number and the interactive effects were less significant than in the quarterly tests. Of the 3 consecutive tests, only Test 2 was significantly different (SNK, $\mathrm{p}=0.05$ ).

The reason for the greater temporal variability in the 4 quarterly tests is unknown; few studies have addressed this issue. One source of variability may be seasonal fluctuations in the general health of adult plants from which the sporophylls were collected. Marine algae are dependant on ambient nutrients which fluctuate seasonally. Nitrogen (as $\mathrm{NO}_{3}{ }^{-}$and $\mathrm{NH}_{4}{ }^{+}$) in particular, may be limiting during certain times of the year (Jackson 1977, Gerard 1982). In southern California, nitrogenlimiting conditions generally occur in late summer and fall when upwelling is reduced (North et al. 1982). In central California the water is cooler, upwelling is more consistent, and nitrogen-limiting conditions occur less frequently (Broenkow \& Smethie 1978, Gerard 1982). It is possible, however, that seasonal fluctuations in the availability of nutrient may have affected the plants at our collection site. If the plants were nutrient limited, it is reasonable to infer that their spores were likewise affected, perhaps increasing their sensitivity to toxicants. No nutrients were added in the quarterly $48 \mathrm{~h}$ experiments.

Another possible explanation for the greater variability in the quarterly tests is variation in the chelating capacity of the dilution water used in the experiments. Cupric ions, the form of copper toxic to algae (Sunda \& Guilliard 1976), are bound by particles and dissolved organic compounds (Kuwabara 1983). Natural chelators (e.g. surface polysaccharides and polyphenols) released by the sporophylls may also bind divalent ions (Haug \& Smidsrod 1965, Ragan et al. 1979). Variation in the amount of chelators present could contribute to between-test variability. Total copper concentration, not cupric ions, was measured, so the amount of chelation is unknown. The number of spores introduced to the test containers was more consistent in the 3 consecutive tests, and more care was taken to adjust the spore density and the volume of water in which the spores were pipeted to the test containers. This could affect chelation. For example, greater spore numbers might increase chelation. We investigated this possibility, however, and found no correlation between spore numbers and NOEC's $\left(\mathrm{r}^{2}=\right.$ $0.33, \mathrm{~N}=4$; data not shown).

The 3 consecutive tests used spores obtained from 1 plant while the 4 quarterly tests used spores obtained from a pooled sample of sporophylls from several plants. Because the interpopulation comparisons showed no significant differences between plants from widely separated areas (Fig. 1), differences among pooled plants from the same population were assumed to be negligible. Also, a mixture of spores from pooled sporophylls would presumably dampen any betweenplant variability. 


\section{Endpoint comparisons}

Reproduction (sporophyte production) was the most sensitive indicator of copper toxicity of the 4 endpoints compared. Sporophyte production was inhibited at the lowest copper concentration tested (Fig. 4a). The next endpoint, sporophyte growth, was variable and was significantly inhibited at $32 \mu \mathrm{g} \mathrm{l}^{-1}$ (NOEC $=10.2 \mu \mathrm{g}$ $1^{-1}$ ). Germ-tube growth was significantly inhibited at $32 \mu \mathrm{g} \mathrm{l}^{-1}\left(\mathrm{NOEC}=10.2 \mu \mathrm{g} \mathrm{l}^{-1}\right)$, and germination was significantly inhibited at $100 \mu \mathrm{g} \mathrm{l} \mathrm{l}^{-1}$ (NOEC $=50.1 \mu \mathrm{g}$ $\mathrm{l}^{-1}$ ). Other researchers have found reproduction to be a more sensitive indicator of copper toxicity than spore germination or vegetative growth. Results of experiments with Macrocystis pyrifera and other laminarian algae are consistent. Smith \& Harrison (1978) found that copper inhibited the vegetative growth of 1 -wkold $M$. pyrifera gametophytes at $50 \mu \mathrm{g} \mathrm{l}^{-1}$, while production of eggs by female gametophytes was inhibited at $30 \mu \mathrm{g} \mathrm{I}^{-1}$. Thompson \& Burrows (1984) found that vegetative growth of Laminaria saccharina sporophytes was inhibited at $50 \mu \mathrm{g}^{-1}$, and reproduction (sporophyte production) was inhibited at $10 \mu \mathrm{g} 1^{-1}$ copper. Chung \& Brinkhuis (1986) found that the release of $L$. saccharina zoospores, gametophyte growth, and gametogenesis were inhibited at copper concentrations greater than $50 \mu \mathrm{g}^{-1}$. Hopkin \& Kain (1978) found that gametophyte germination in Laminaria hyperborea was inhibited at $100 \mu \mathrm{g}^{-1}$ and sporophyte growth was inhibited at $10 \mu \mathrm{g} \mathrm{l}^{-1}$.

Although less sensitive than sporophyte production, inhibition of germ-tube growth and germination have been proposed as routine indicators of effluent toxicity because they require considerably less technical expertise, are relatively reliable in repetitive tests, and take only $48 \mathrm{~h}$ to evaluate (Anderson \& Hunt 1988). The drawbacks are that they are somewhat less sensitive than the reproductive endpoint, and the ecological relevance is less easily defended because it is not clear how declines in germ-tube growth affect field populations. Copper concentrations inhibiting germ-tube growth also inhibit reproduction. Germination is a less sensitive and more variable indicator of toxicity, but its ecological relevance is more obvious: if spores do not germinate they will not develop.

\section{Copper toxicity}

The primary mechanism of copper toxicity to Macrocystis pyrifera gametophytes is unknown. We previously suggested that metals might inhibit spore photosynthesis or the use of stored photosynthate and thus disrupt germination (Anderson \& Hunt 1988). Inhibition of photosynthesis does not appear likely consider- ing Lüning's (1980) finding that germination and production of the first gametophytic cell in Laminaria species can occur in complete darkness. We have also found that $M$. pyrifera spores can germinate and grow in the dark and that copper inhibits these processes in experiments conducted in complete darkness (Anderson \& Hunt unpubl.). Amsler has demonstrated that the photosynthetic rate is only slightly greater than the respiration rate in $M$. pyrifera spores, and suggested that stored energy is used for germination (Amsler 1988, C. Amsler, University California Santa Barbara, pers. comm.).

Research into germination and germ-tube growth of pollen grains and Fucus zygotes, cellular systems similar to kelp spores, offer an alternative hypothesis. Work on factors controlling pollen tube elongation of Tradescantia virginiana by Picton \& Steer (1982) and reviewed by Steer (1989) show that calcium ion transport across the cell membrane plays an essential role in controlling tube growth. In their model, $\mathrm{Ca}^{2+}$ ions are pumped into the cell and the increase in internal $\mathrm{Ca}^{2+}$ concentration results in an electrochemical gradient across the cell membrane. This results in a net positive charge, allowing negatively charged vesicles to be drawn towards the growing tip where they fuse. This process, combined with changes in the structure of cytoskeleton microfilaments, results in tip elongation (Picton \& Steer 1982). This model incorporates similar processes described by Jaffe et al. (1976) and more recently reviewed by Kropf (1989) for rhizoid formation in Fucus zygotes. It is possible that the formation of a calcium ion gradient also marks the beginning of germination of $M$. pyrifera spores, and this process may be inhibited by a variety of toxicants, including copper, perhaps by disrupting membrane integrity (Bussler 1981).

Although total copper concentrations in sewage effluent are sometimes within the range toxic to kelp $<<$ 10 to $100 \mu \mathrm{g} \mathrm{l}^{-1}$, depending on test endpoint), ambient concentrations are considerably lower. Average annual copper concentrations compiled for 1988 for 5 major southern California municipal sewage effluents ranged between 32 and $58 \mu \mathrm{g} \mathrm{1^{-1 }}$. Flow rates for these effluents ranged between 704 and 1408 million $1 \mathrm{~d}^{-1}$ (H. Schafer, Southern California Coastal Water Research Project, pers. comm.). Ambient copper concentrations for California coastal waters ranged between 0.5 and 6.0 $\mu \mathrm{g} \mathrm{l}^{-1}$ (Harrison 1982).

Acknowledgements. The manuscript was greatly improved through comments by M. S. Foster and 3 anonymous reviewers. We thank T. Dean, K. Wilson and staff, and C. Amsler for collecting sporophylls for the interpopulation study. This document was prepared through agreement with the California State Water Resources Control Board (CSWRCB Contract No. 7-120-250-0). Primary funding for this study has been provided by the CSWRCB using Section 205 (j) grant funds 
made available by the United States Environmental Protection Agency. This does not signify that the contents reflect the views and policies of the US EPA or the CSWRCB, nor does mention of trade names or commercial products constitute endorsement or recommendation for use.

\section{LITERATURE CITED}

Anderson, B. S., Hunt, J. W. (1988). Bioassay methods for evaluating the toxicity of heavy metals, biocides, and sewage effluent using microscopic stages of giant kelp Macrocystis pyrifera (Agardh): a preliminary report. Mar. environ. Res. 26: 113-134

Amsler, C. D. (1988). Kelp spore photosynthesis, respiration, and pigmentation. J. Phycol. (abstract supplement to June 1988) $24: 4$

American Society for Testing and Materials (1987). Annual book of ASTM standards: water and environmental technology. ASTM, Philadelphia, Vol. 11.4, p. 374-390

Bay, S. M., Oshida, P. S., Jenkins, K. D. (1983). A simple new bioassay based on echinochrome synthesis by larval sea urchins. Mar. environ. Res. 8: 29-39

Broenkow, W., Smethie, W. (1978). Surface circulation and replacement of water in Monterey Bay. Estuar. coast. mar. Sci. 6: 583-603

Bruland, K. W., Franks, R. P., Knauer, G. A., Martin, J. H. (1979). Sampling and analytical methods for the determination of copper, cadmium, zinc, and nickel at the nannogram per liter level in seawater. Analytica Chem. Acta 150: $233-245$

Bussler, W. (1981). Physiological functions of copper. In: Woolhouse, H. W., Walker, S. (eds.) Copper in soils and plants. Academic Press, Sydney, p. 213-262

Chung, I. K., Brinkhuis, B. H. (1986). Copper effects in early life stages of kelp, Laminaria saccharina. Mar. Pollut. Bull. 17: $213-218$

Dinnel, P. A., Link, J. M., Stober, Q. (1987). Improved methodology for a sea urchin sperm cell bioassay for marine waters. Archs environ. Contam. Toxicol. 16: 23-32

Foster, M. S., Schiel, D. R. (1985). The biology of giant kelp forests in California: a community profile. U.S. Fish Wildl. Serv. biol. Rep. 85 (7.2), Washington D.C.

Gerard, V. A. (1982). In situ rates of nitrate uptake by giant kelp, Macrocystis pyrifera (L.) C. Agardh, tissue differences, environmental effects, and predictions of nitrogen limited growth. J. exp. mar. Biol Ecol. 62: 51-54

Gerard, V. A. (1988). Ectotypic differentiation in Laminaria saccharina. J. Phycol. (abstract supplement to June 1988) 24: 20

Hall, A., Fielding, A. H., Butler, M. (1981). Mechanisms of copper tolerance in the marine fouling alga Ectocarpus siliculosus - evidence for an exclusion mechanism. Mar. Biol. 54: 195-199

Harrison, F. L. (1982). A review of the impact of copper released into marine and estuarine environments. Report to the U.S. Nuclear Regulatory commission, Lawrence Livermore National Laboratory, Livermore, California. NUREG/CR-2823. UCRL-53042

Haug, A., Smidsrod, O. (1965). The effect of divalent metals on the properties of alginate solutions. II. Comparison of different metal ions. Acta Chem. Scand. 19: 341-351

Hopkin, R., Kain, J. M. (1978). The effects of some pollutants on survival, growth and respiration of Laminaria hyperborea. Estuar, coast. mar. Sci. 7: 531-553

Hunt, J. W., Anderson, B. S. (1989). Sublethal effects of zinc and municipal sewage effluent on larvae of the red abalone Haliotis rufescens. Mar. Biol. 101 (4): 545-552
Jackson, G. A. (1977). Nutrients and production of the giant kelp Macrocystis pyrifera off southern California. Limnol. Oceanogr. 22: 979-995

Jaffe, L. F., Robinson, K. R., Nuccitelli, R. (1976). Local cation entry and self electrophoresis as an intracellular localization mechanism. Ann. N.Y. Acad. Sci. 238: 372-389

James, D. F., Manley, S. L., Carter, M. C., North, W. J. (1987). Effects of PCB's and hydrazine on life processes in microscopic stages of selected brown seaweeds. Hydrobiologia 151/152: 411-415

Kropf, D. L. (1989). Calcium and early development in fucoid algae. Biol. Bull. mar. biol. Lab., Woods Hole 176(s): 5-8 (April 1989, suppl.)

Kuwabara, J. S. (1983). Effects of trace metals and natural organics on algae. In: Bascom, W. (ed.) The effects of waste disposal on kelp communities. Southern California Coastal Water Research Project, Long Beach, p. 136-146

Lüning, K. (1980). Critical levels of light and temperature regulating the gametogenesis of three Laminaria species (Phaeophyceae). J. Phycol. 16: 1-15

Lussier, S. M., Gentile, J. H., Walker, J. (1985). Acute and chronic effects of heavy metals and cyanide on Mysidopsis bahia (Crustacea: Mysidacea). Aquat Toxicol. 7: 25-35

Markham, J. W., Hagmeier, E. (1982). Observations on the effects of germanium dioxide on the growth of macroalgae and diatoms. Phycologia 21 (2): 125-130

Martin, M., Stephenson, M. D., Martin, J. (1977). Copper toxicity experiments in relation to abalone deaths observed in a power plants cooling waters. Calif. Fish Game 63: 95-100

Martin, M., Osborn, K. E., Billig, P., Glickstein, N. (1981). Toxicities of ten metals to Crassostrea gigas and Mytilus edulis embryos and Cancer magister larvae. Mar. Pollut. Bull. 12: 305-308

Martin, M., Hunt, J. W., Anderson, B. S., Turpen, S. L., Palmer, F. H. (1989). Experimental evaluation of the mysid Holmesimysis costata as a test organism for effluent toxicity testing. Environ. Toxicol. Chem. 8: 1003-1012

Middaugh, D., Hemmer, M. J., Lores, E. M. (1988). Teratological effects of 2,4-dinitrophenol 'produced water' and naphthalene on embryos of the inland silverside Menidia beryllina. Dis. aquat. Org. 4: 53-65

North, W. J. (1971). The biology of giant kelp beds (Macrocystis) in California. Nova Hedwigia 32: 1-600

North, W., Gerard, V. A., Kuwabara, J. S. (1982). Farming Macrocystis at coastal and oceanic sites. In: Srivastava, L. (ed.) Synthetic and degradative processes in marine macrophytes. Walter de Gruyter, Berlin, p. 247-264

Picton, J. M., Steer, M. W. (1982). A model for the mechanism of tip extension in pollen tubes. J. theor. Biol. 98: 15-20

Provasoli, L. (1968). Media and prospects for the cultivation of marine algae. In: Watanabe, A., Hattori, A. (eds.) Cultures and collections of algae. Proc. U.S.-Japan Conference, Hakone. Japanese Society of Plant Physiology, Tokyo, p. 63-75

Ragan, M. A., Smidsrod, O., Larsen, B. (1979). Chelation of divalent metal ions by brown algal polyphenols. Mar. Chem. 7: 265-271

Reed, R. H., Moffat, L. (1983). Copper toxicity and copper tolerance in Enteromorpha compressa (L.) Grev. J. exp. mar. Biol. Ecol. 69: 85-103

Russell, G., Morris, O. P. (1970). Copper tolerance in the marine fouling alga Ectocarpus siliculosus. Nature, Lond. 228: 288-289

Smith, B. M., Harrison, F. L. (1978). Sensitivity of Macrocystis gametophytes to copper. Final report to US Nuclear Regulatory Commission, Lawrence Livermore National 
Laboratory, Livermore, California. NRC FIN No. A0119: $1-34$

Southern California Coastal Water Research Project (1986). Characteristics of municipal wastewater 1984-1985. SCCWRP Annual Report, Long Beach p. 1-5

Steer, M. W. (1989). Calcium control of pollen tube growth. Biol. Bull. mar. biol. Lab., Woods Hole 176(s): 18-20 (April 1989 suppl.)

Sunda, W. G., Guilliard, R. R. L. (1976). The relationship between cupric ion activity and the toxicity of copper to phytoplankton. J. mar. Res. 35: 511-29

Thompson, R. S., Burrows, E. M. (1984). The toxicity of copper, zinc, and mercury to the brown macroalga Laminaria sac-

This article was submitted to the editor charina. In: Persoone, G., Jaspers, E., Claus, C., (eds.) Ecotoxicological testing for the marine environment. Vol. 2. State Univ. Ghent and Inst. Mar. Scient. Res., Brendene, p. 259-269

Underwood, A. J. (1981). Techniques of analysis of variance in experimental marine biology and ecology. Oceanogr. mar. Biol. A. Rev. 19: 513-605

Zar, J. H. (1974). Biostatistical analysis. Prentice-Hall, Inc. Englewood Cliffs

Zimmerman, R. C. (1988). Enzymology of nitrogen metabolism in physiological ecotypes of the giant kelp, Macrocystis pyrifera. J. Phycol. (Abstract supplement to June 1988) 24: 16

Manuscript first received: February 27, 1990 Revised version accepted: August 22, 1990 